\title{
Proteomic analysis of the inhibitory effect of chitosan on Penicillium expansum
}

\author{
Mingyan $\mathrm{LI}^{1}$, Chi CHEN ${ }^{1}$, Xiaoshuang XIA ${ }^{1}$, Betchem GARBA ${ }^{1}$, Linlin SHANG ${ }^{1}$, Yun WANG ${ }^{1 *}$
}

\begin{abstract}
The antimicrobial effect of chitosan on Penicillium expansum, a major postharvest pathogen of pome fruit, and the possible mechanisms involved in its effect were examined in this study. Chitosan strongly inhibited spore germination and hyphal growth of P. expansum. Light microscopy and transmission electron microscopy observations revealed that chitosan also caused morphological changes in hyphae and conidia, such as abnormal branching and vacuolation. Proteomic changes in P. expansum after chitosan treatment were analyzed by two-dimensional electrophoresis (2-DE) and mass spectrometry (MS) analysis, and 26 proteins were ambiguously identified and categorized based on their putative biological function. Proteins related to DNA or protein biosynthesis, carbohydrate metabolism and energy production were decreased in relative protein abundance, while proteins involved in antibiotics resistance and defense response increased in relative protein abundance. Changes in abundance of these identified proteins were in accordance to the observed physiological and morphological changes of the fungi cells. Altogether, these experimental results provide a detailed illustration of the responses to chitosan in $P$. expansum, and widen our knowledge on the potential antifungal mechanisms of chitosan.
\end{abstract}

Keywords: chitosan; Penicillium expansum; antifungal activity; proteomics.

Practical application: Antifungal activity of chitosan against $P$. expansum and its possible mechanisms.

\section{Introduction}

The fungal pathogen Penicillium expansum is the causal agent of a major postharvest disease in pome fruits known as blue mold decay. In addition to causing economic losses, P. expansum also can produce patulin mycotoxin, a highly toxic compound that is harmful to both humans and animals therefore raising potential public health significance (Andersen et al., 2004; Puel et al., 2010). Currently, chemical fungicides are still the main strategy to control postharvest diseases; however, the appearance of resistance in pathogens together with growing public concern about environmental safety and human health associated with the use of chemical substances have impose necessity to explore new alternatives for postharvest diseases management (Zhang et al., 2011; Liu et al., 2013).

Chitosan, the deacetylation product of chitin, has been recently used as a promising alternative postharvest diseases management. Diverse studies have shown the efficiency of chitosan in controlling postharvest rot of horticultural commodities caused by plant pathogenic fungi, such as Aspergillus flavus (Dias et al., 2018), Botrytis cinerea (Lopes et al., 2014), Ceratocystis fimbriata (Xing et al., 2018), Pilidiella granati (Munhuweyi et al., 2017) and P. expansum (Wang et al., 2014). In addition to its potential to elicit plant defense by increasing the production of defense-related secondary metabolites and promoting the expression of defense-related enzymes (Hadwiger, 2013), chitosan also exhibits direct antimicrobial activities against plant pathogens (Xing et al., 2015). A number of researches have revealed that the antimicrobial mechanisms of chitosan can be partially explained by electrostatic interaction between the protonated amino group $\left(-\mathrm{HN}_{3}{ }^{+}\right)$on chitosan chain and the negatively charged components at the microbial surfaces, thereby increasing the plasma membrane permeability and causing the death of microorganisms (Garcia-Rincon et al., 2010; Olicón-Hernández et al., 2015). Furthermore, chitosan is presumed to be able to cross microbial cell membrane, destroy intracellular components, disrupt the normal physiological processes, or directly bind to genetic materials, interfere with DNA replication and ultimately resulting in the death of pathogens (Palma-Guerrero et al., 2009; Xing et al., 2015). Nevertheless, the responses to chitosan in plant pathogenic fungi are far from well known, especially the responses occurred at omics level.

Proteomic profiling by two-dimensional gel electrophoresis (2-DE) combined with mass spectrometry (MS) has been successfully used to analyze the global changes of protein expression in biological organisms under various environmental conditions (Wang et al., 2013; Yuan et al., 2014). In the present work, our aim is (i) to investigate the effect of chitosan on fungal growth, morphological and ultrastructural characteristics of P. expansum, (ii) to reveal the proteomic response of $P$. expansum to chitosan and elucidate the possible mechanisms of antifungal activity of chitosan.

\section{Materials and methods}

\subsection{Penicillium expansum strain}

P. expansum (CGMCC 3.3703) isolated from rotten fruits was obtained from the China General Microbiological Culture Collection Center, and its ability to cause postharvest decay of 
apples and the accumulation of patulin in diseased fruits have been discussed in our previous report (Li et al., 2015).

\subsection{Chitosan solution}

Chitosan, with an average molecular weight of $100 \mathrm{kDa}$ and an approximate deacetylation degree of $93 \%$, was provided by Golden-Shell Pharmaceutical Co., Ltd. (Yuhuan, China). Chitosan stock solution was prepared by dissolving $1 \mathrm{~g}$ of chitosan in $100 \mathrm{~mL}$ of $1 \%(\mathrm{w} / \mathrm{v})$ acetic acid under stirring overnight and adjusting $\mathrm{pH}$ to 5.6 with $1 \mathrm{~mol} / \mathrm{L} \mathrm{NaOH}$. After filtration, the resulting solution was used to prepare chitosan amended fungal culture media at different concentrations.

\subsection{Spore germination assay}

Conidia of $P$. expansum used in this experiment were harvested by flooding with sterile water from 7-day-old sporulated potato dextrose agar (PDA) plate. Test samples containing $10^{4}$ spores $\mathrm{mL}^{-1}$ in potato dextrose broth (PDB) medium amended with chitosan at different concentrations $(0.01 \%, 0.05 \%$ and $0.1 \%$ ) were incubated at $25 \circ \mathrm{C}$ for $12 \mathrm{~h}$ in darkness. PDB medium amended with diluted acetic acid solution ( $\mathrm{pH} 5.6$ ) served as control. Spores were observed under an Eclipse Ci-L light microscope (Nikon) by using a haematocytometer. A spore with germ tube length higher than 1.5 times the spore diameter was considered germinated (Plascencia-Jatomea et al., 2003).

\subsection{Fungal growth measurement}

Agar disc (diameter $0.5 \mathrm{~cm}$ ) cut from the edge of actively growing culture of $P$. expansum was placed mycelium side down in the center of a fresh PDA culture plate supplemented with chitosan at different concentrations. After incubation at $25^{\circ} \mathrm{C}$ for 7 days, growth of $P$. expansum mycelium was assayed by measuring colony diameter. Mycelium from the margin of the colony was collected for light microscope observation.

One milliliter of conidial suspension adjusted to $10^{7}$ spores $\mathrm{mL}^{-1}$ was added to conical flasks containing $50 \mathrm{~mL}$ of PDB medium amended with chitosan at different concentrations. After 7 days incubation on a rotary shaker at $180 \mathrm{rpm}$ and $25^{\circ} \mathrm{C}$, the culture liquids were filtered and the biomass obtained with each concentration was weighed.

\subsection{Transmission electron microscopy}

Conidia of $P$. expansum, either treated or untreated with $0.05 \%$ chitosan for $6 \mathrm{~h}$, were fixed by immersion in cold $2.5 \%$ $(\mathrm{v} / \mathrm{v})$ glutaraldehyde at $4{ }^{\circ} \mathrm{C}$ for $8 \mathrm{~h}$. After washing three times with phosphate buffered solution $(0.2 \mathrm{~mol} / \mathrm{L}, \mathrm{pH} 7.4)$, conidia were postfixed with $0.1 \%$ osmium tetroxide for $2 \mathrm{~h}$ at room temperature and washed three times again with the same buffer. Subsequently, samples were dehydrated in a graded acetone series $(50 \%, 60 \%, 70 \%, 80 \%$ and $90 \%$, v/v) with 15 min per change, and then embedded in Epon 812 (Electron Microscopy Sciences, Fort, WA, USA). 60-nm-thick ultrathin sections were made using a diamond knife blade and collected on Formvar-coated copper grids. Sections were stained in uranyl acetate for $30 \mathrm{mins}$ and in lead citrate for 10 mins. The grids were examined with a Philips CM100 transmission electron microscopy (FEI Company, Darmstadt, Netherlands).

\subsection{Protein extraction}

Total protein extraction was performed according to trichloroacetic acid (TCA)-acetone precipitation protocol as described by Cai et al. (2014). In brief, mycelia were grounded to fine powder using a pre-cooled mortar and pestle under liquid nitrogen. The samples were suspended in ice-cold $10 \%(\mathrm{w} / \mathrm{v})$ TCA in acetone and kept at $4{ }^{\circ} \mathrm{C}$ for $2 \mathrm{~h}$. The precipitates were collected by centrifugation at $10000 \mathrm{~g}$ for $10 \mathrm{~min}$ and washed three times with $80 \%$ ice-cold acetone. After air dried to near dryness at room temperature, the pellets were suspended for protein solubilization in a small volume of lysis buffer containing $8 \mathrm{M}$ urea, $2 \mathrm{M}$ thiourea, $20 \mathrm{mM}$ DTT, 4\% 3-[(3-cholamidopropyl) dimethylammonio]-1-pro-panesulfonate (CHAPS) and 1\% Carrier Ampholyte ( $\mathrm{pH} 4-7)$. Finally, the resulting lysates were vortexed overnight at room temperature followed by centrifugation at $16000 \mathrm{~g}$ for $10 \mathrm{~min}$, at $4{ }^{\circ} \mathrm{C}$. Protein content was estimated following the method of Bradford, with bovine serum albumin (BSA) as a standard.

\subsection{Two-dimensional gel electrophoresis}

A total of $800 \mu \mathrm{g}$ of protein were loaded into IPG strips (17 cm, pH 4-7 linear gradient) using in-gel passive rehydration at $17^{\circ} \mathrm{C}$ for $12 \mathrm{~h}$. The first isoelectric focusing (IEF) was carried out on a PROTEAN IEF Cell (Bio-Rad Co., Ltd., Hercules, USA) with a gradually increasing voltage: $0-250 \mathrm{~V}, 30 \mathrm{~min} ; 250-1000 \mathrm{~V}$, $30 \mathrm{~min} ; 1000-8000 \mathrm{~V}, 120 \mathrm{~min}$ and to a total of $60 \mathrm{kVh}$ with a maximum voltage of $8,000 \mathrm{~V}$ at $17^{\circ} \mathrm{C}$. After focusing, the IPG strips were subjected to reduction and alkylation by incubating in equilibration buffer consisting of $0.075 \mathrm{M}$ Tris- $\mathrm{HCl} \mathrm{pH} \mathrm{8.8,}$ $7 \mathrm{M}$ urea, 2\% (w/v) SDS, 30\% (v/v) glycerol together with $1 \%$ $(\mathrm{w} / \mathrm{v})$ DTT for $15 \mathrm{~min}$, and subsequently in the same buffer containing $2.5 \%(\mathrm{w} / \mathrm{v})$ iodoacetamide for $15 \mathrm{~min}$. The second dimension electrophoresis was run on $12 \%$ polyacrylamide gel with a PROTEAN Plus Dodeca Cell (Bio-Rad Co., Ltd., Hercules, USA). 2-DE gels were stained with colloidal Coomassie blue G-250 overnight. Gel images were captured using a GS-900 densitometer (Bio-Rad Bio-Rad Co., Ltd., Hercules, USA). Scanned images were analyzed using PDQuest v7.4 image analysis software (Bio-Rad Co., Ltd., Hercules, USA) according to the manual protocol. The intensity of each protein spot was normalized as a percentage of the total quantity of valid spots detected on the gel. Normalized abundance of each spot between the treatments and controls were compared, and only those protein spots showed at least a 1.5 fold variation in relative intensity $(p<0.05)$ were considered as differentially expressed.

\subsection{Protein identification}

Spots of interest were excised from gels manually and transferred into microtubes. After destaining with 50\% (v/v) acetonitrile containing $50 \mathrm{mM} \mathrm{NH}_{4} \mathrm{HCO}_{3}$, gel pieces were reduced in $50 \mu \mathrm{L}$ 
of $10 \mathrm{mM} \mathrm{DTT}$ in $100 \mathrm{mM} \mathrm{NH}_{4} \mathrm{HCO}_{3}$ at $55^{\circ} \mathrm{C}$ for $45 \mathrm{~min}$, and then subjected to alkylation by incubating in $50 \mu \mathrm{L}$ of $55 \mathrm{mM}$ iodoacetamide in $100 \mathrm{mM} \mathrm{NH}_{4} \mathrm{HCO}_{3}$ at room temperature in the dark for $45 \mathrm{~min}$. Afterwards, gel pieces were dehydrated by $50 \%(\mathrm{v} / \mathrm{v})$ acetonitrile containing $50 \mathrm{mM} \mathrm{NH}_{4} \mathrm{HCO}_{3}$ and dried in a vacuum centrifuge. Finally, $0.1 \mu \mathrm{g}$ of sequencing grade trypsin (Sigma-Aldrich (Shanghai) Trading Co. Ltd., Shanghai, China) in sufficient $100 \mathrm{mM} \mathrm{NH}_{4} \mathrm{HCO}_{3}$ was added into the microtube to submerge the gel piece in the solution. After tryptic digestion at $37^{\circ} \mathrm{C}$ overnight, peptide mixtures were carefully collected.

Peptide mixtures were analyzed in an Ultraflex MALDI-TOF/TOF mass spectrometer (Bruker Daltonics, Bremen, Germany). The peptide mass fingerprinting (PMF) data resulting from the MS analysis were queried against non-redundant NCBI database using the MASCOT searching program (http://www.matrixscience.com). All searches were performed with the following parameters: taxonomy restrictions to other fungi, allowance of one missed cleavage, cysteine carbamidomethylation as fixed modification, mass value $\mathrm{MH}^{+}$, monoisotopic and fragment mass tolerance of $0.2 \mathrm{Da}$.

\subsection{Statistical analysis}

Data of chitosan treatments and the control were subjected to one way ANOVA analysis using SPSS version 17.0 software (SPSS Inc., Chicago, USA) for Windows. Means comparison was performed using Duncan's multiple range test with $P<0.05$.
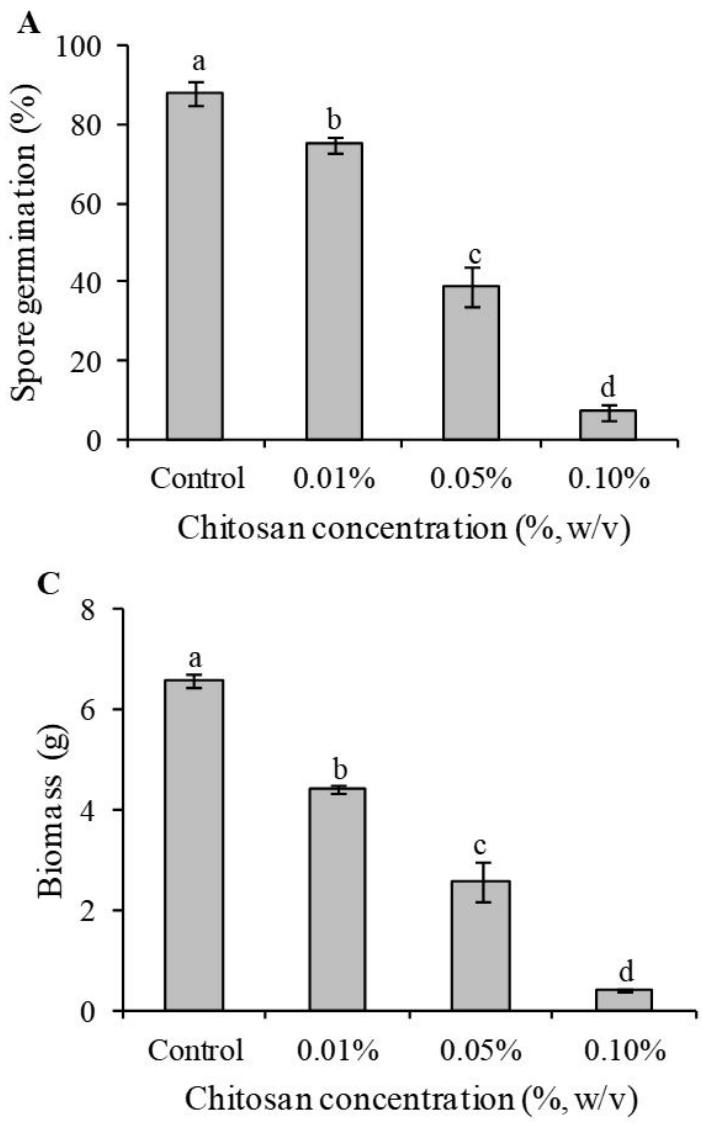

\section{Results and discussion}

\subsection{Effect of chitosan on spore germination and fungal growth}

The results obtained for fungal spore germination were presented in Figure 1A. The fungistatic effect of chitosan gradually increased with the chitosan concentration, resulting in about $39 \%$ of spore germination rate in media with $0.05 \%$ chitosan and $9 \%$ of that in media with $0.1 \%$ chitosan, whereas the spore germination rate in the control was nearly $92 \%$.

Effect of chitosan on mycelial growth was estimated by measuring the colony diameter of $P$. expansum on PDA supplemented with different chitosan concentrations. As shown in Figure 1B, the degree of inhibition was directly correlated to the chitosan concentration. After 7 days of incubation, fungal colony grew up to $41.2 \mathrm{~mm}$ in diameter on the control PDA, but the colony diameter was only $37.5,31.4$ and $23.9 \mathrm{~mm}$ on PDA supplemented with $0.01 \%, 0.05 \%$ and $0.1 \%$ chitosan, presenting inhibition rate of $9.0 \%, 23.8 \%$ and $42.0 \%$ respectively (Figure 1B).

When a liquid PDB culture was used, the mycelial biomass of untreated cultures reached $6.6 \mathrm{~g}$ after 7 days of incubation, whereas the mycelial biomass in PDB amending $0.05 \%$ and $0.1 \%$ chitosan was only $2.6 \mathrm{~g}$ and $0.4 \mathrm{~g}$ with approximately $60.6 \%$ and $93.9 \%$ growth inhibition, respectively (Figure 1C). P. expansum grown in liquid medium exhibited more sensitive to chitosan than those grown in solid medium. Similar results were reported by Prapagdee et al. (2007) for Fusarium solani

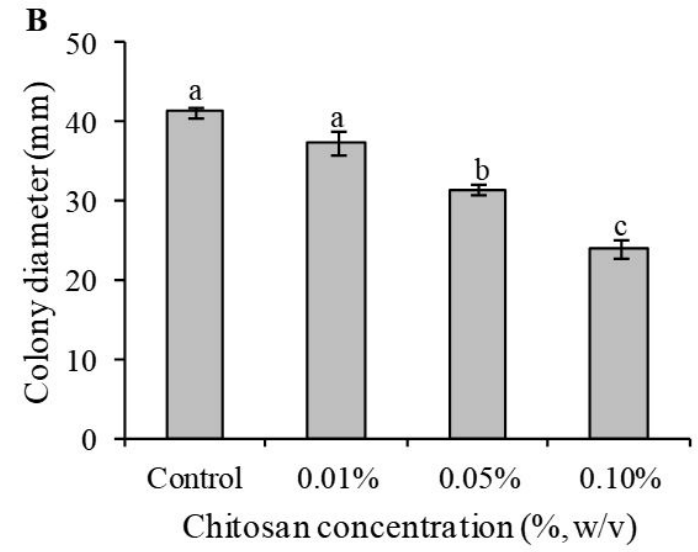

Figure 1. Effect of chitosan on spore germination (A), mycelial growth (B) and biomass accumulation (C) of P. expansum. Values represent the mean \pm SD of three biological replicates and the different letters within each parameter indicate statistically significant differences $(\mathrm{p}<0.05)$. 
and Al-Hetar et al. (2011) for F. oxysporum, possibly due to the cells cultured in liquid medium were entirely in contact with the added chitosan (El Hassni et al., 2004).

Both spore germination and mycelial growth were inhibited by chitosan clearly demonstrating its effects on various growth and development stages of $P$. expansum. Similar antifungal activities of chitosan against other plant pathogenic fungi have been observed, such as F. oxysporum (Palma-Guerrero et al., 2008), A. parasiticus (Cota-Arriola et al., 2011) and A. flavus (Dias et al., 2018). Moreover, about $60 \%$ spore germination and mycelium growth of $P$. expansumin in liquid medium were inhibited by chitosan at concentration of $0.05 \%$, which is very close to the observed $50 \%$ inhibition concentrations of chitosan for Alternaria alternate, F. oxysporum and Pythium debaryanum (Rabea \& Steurbaut, 2010).

\subsection{Morphological changes in response to chitosan}

As shown in Figure 2, chitosan treatment induced remarkable changes in $P$. expansum morphology characterized by hyphal agglomeration, presence of large vesicles in the hyphae, and abnormal shapes, such as bifurcation and swollen. Without chitosan treatment, hyphae showed even and branches formed at considerable distance from the apical tip of hyphal cell. While the conidia subjected to chitosan, intense vacuolization inside the cell and membrane rupture were observed (Figure 3). Microscopy observations showed that both conidia and mycelium of $P$. expansum were severely damaged by chitosan treatment. Similar effects were reported for F. oxysporum (Palma-Guerrero et al. 2008) and Ustilago maydis (Olicón-Hernández et al. 2015). The antifungal activity of chitosan might be attributed to its structural capability to bind to the negatively charged components presented on fungal cell surface via electrostatic interactions, which resulted in membrane leakage (Xing et al., 2015). Therefore, abnormal morphological changes, cell membrane disruption and loss of cellular materials could account for the inhibitory effect of chitosan on spore germination and mycelial growth.

\subsection{Changes in protein expression profiles in response to chitosan}

Cell growth and morphological analysis indicated that chitosan with concentration of $0.05 \%(\mathrm{w} / \mathrm{v})$ could exert effective inhibition on fungal growth both in liquid and solid medium. Therefore, to gain insight into the antifungal activity of chitosan
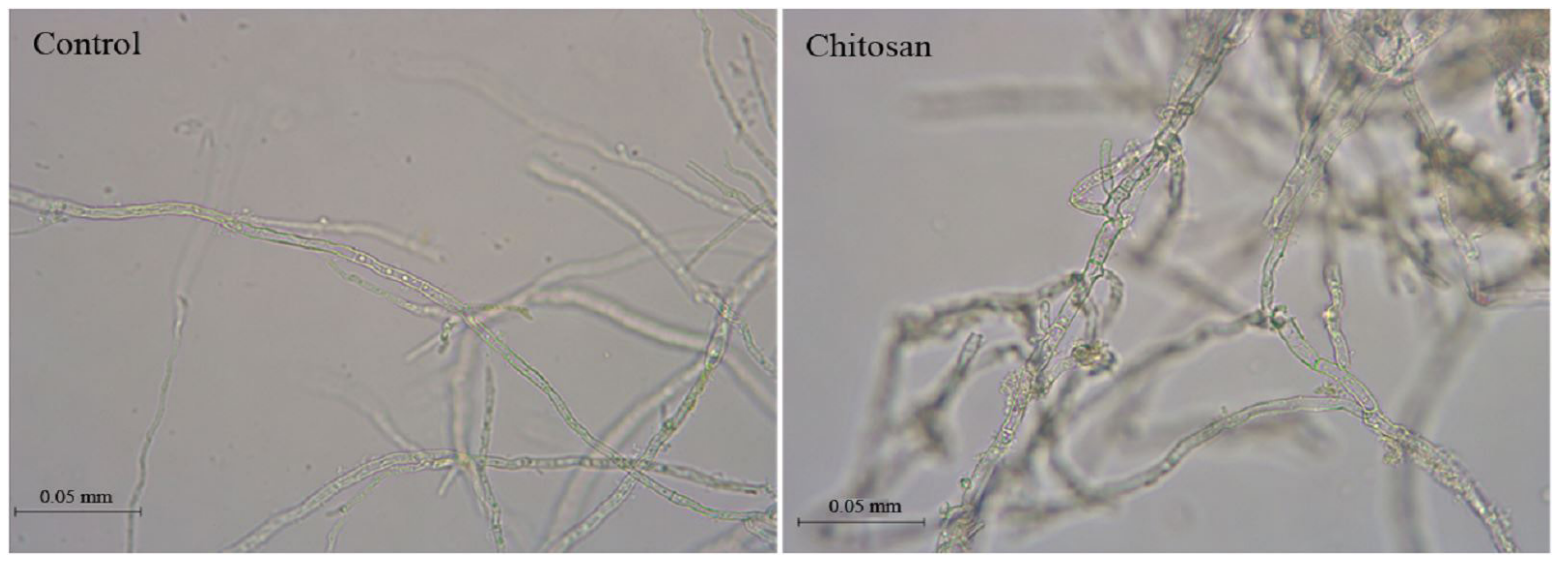

Figure 2. Light micrographs of $P$. expansum mycelia after 7 days of cultivation with or without $0.05 \%$ chitosan treatment.
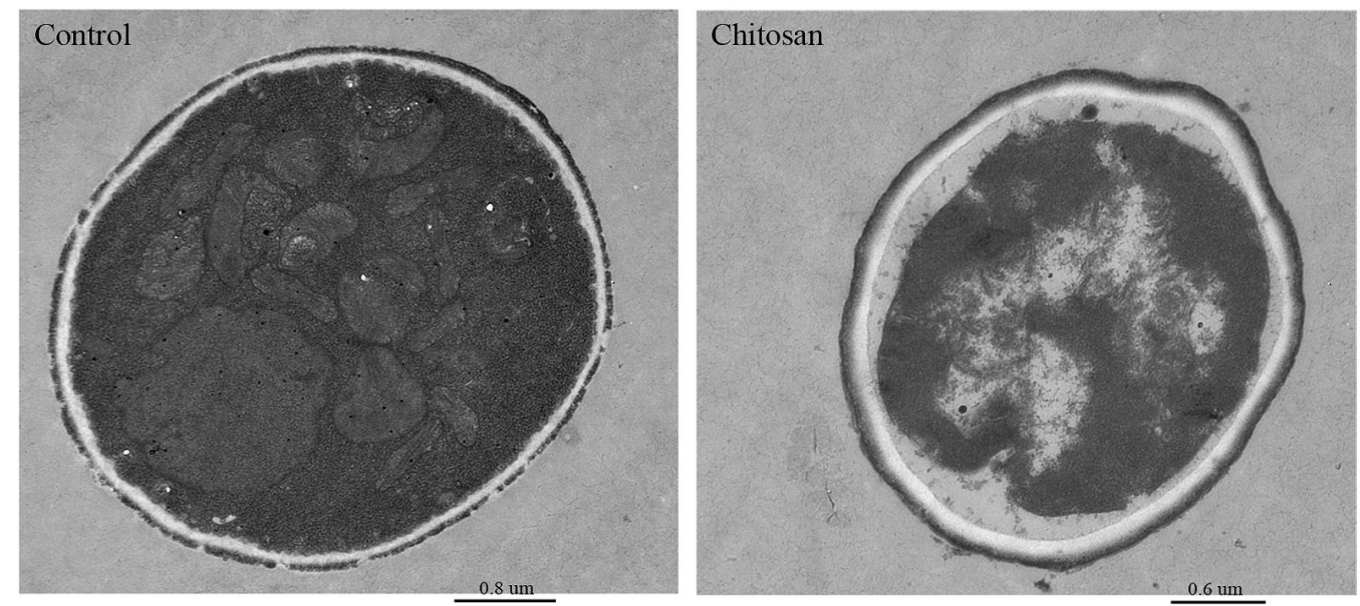

Figure 3. Transmission electron micrographs of P. expansum conidia after $6 \mathrm{~h}$ of cultivation with or without $0.05 \%$ chitosan treatment. 
against $P$. expansum, spores after incubation with or without $0.05 \%$ chitosan for $12 \mathrm{~h}$ were collected for further proteomic analysis. Each CBB stained 2-DE gel revealed that about 500 protein spots were well resolved and detected in $\mathrm{pH} 4-7$ and molecular weight $14-110 \mathrm{kDa}$ (Figure 4), and a total of 42 spots showed at least 1.5 fold difference in relative abundance in response to chitosan treatment. All the differentially expressed proteins were analyzed by MALDI-TOF MS followed by MASCOT database search, and 26 of them were identified unambiguously with an identification rate of $62 \%$ (Table 1). According to their putative biological function, these identified proteins were classified into 6 categories, including DNA or protein biosynthesis, carbohydrate metabolism and energy production, antibiotic resistance and defense response, protein transport, secondary metabolism and unknown.

Among the identified proteins, several proteins involved in DNA or protein biosynthesis with reduced expression level were identified, including nucleic acid-binding ( $\operatorname{spot} 2$ ), aminoacyl-tRNA synthetase (spot 4 and 12), ribosomal protein S14 (spot 1), ribosomal protein S2 (spot 17), ribosome assemble protein

Table 1. List of differentially expressed proteins in P. expansum after chitosan treatment.

\begin{tabular}{|c|c|c|c|c|c|c|c|c|c|}
\hline Spot & Protein name & $\begin{array}{l}\text { Accession } \\
\text { Number }\end{array}$ & $\begin{array}{c}\mathrm{Mr} \\
(\mathrm{kDa})\end{array}$ & $\mathrm{pI}$ & Score & $\begin{array}{l}\text { Matched } \\
\text { peptides }\end{array}$ & $\begin{array}{c}\text { Sequence } \\
\text { coverage } \\
(\%)\end{array}$ & $\begin{array}{l}\text { Fold } \\
\text { change }\end{array}$ & Species \\
\hline \multicolumn{10}{|c|}{ DNA/protein biosynthesis } \\
\hline 1 & Ribosomal protein S14 & KGO56193.1 & 72.8 & 5.6 & 79 & 7 & 17 & 0.55 & P. expansum \\
\hline 2 & Nucleic acid-binding, OB-fold & XP_016595516.1 & 61.0 & 5.4 & 80 & 6 & 22 & 0.49 & P. expansum \\
\hline 4 & Aminoacyl-tRNA synthetase, class II & XP_016603573.1 & 57.7 & 6.1 & 88 & 8 & 26 & 0.61 & P. expansum \\
\hline 5 & $\begin{array}{l}\text { Translation elongation/initiation } \\
\text { factor/ribosomal }\end{array}$ & KGO42256.1 & 48.3 & 5.0 & 121 & 22 & 60 & 0.17 & P. expansum \\
\hline 6 & Ribosome assembly protein & ENH78528.1 & 57.0 & 6.7 & 87 & 6 & 27 & 0.21 & $\begin{array}{c}\text { Colletotrichum } \\
\text { orbiculare }\end{array}$ \\
\hline 12 & Aminoacyl-tRNA synthetase & OQE12468.1 & 42.3 & 6.4 & 78 & 6 & 14 & 0.55 & P. vulpinum \\
\hline 17 & Ribosomal protein S2 & KGO50333.1 & 32.4 & 4.8 & 90 & 7 & 37 & 0.43 & P. expansum \\
\hline 24 & Translation elongation factor, IF5A & CRL29786.1 & 23.2 & 7.0 & 77 & 7 & 38 & 0.39 & P. expansum \\
\hline \multicolumn{10}{|c|}{ Carbohydrate metabolism and energy production } \\
\hline 3 & $\begin{array}{l}\text { Thiamine pyrophosphate enzyme, } \\
\text { TPP-binding }\end{array}$ & XP_016597049.1 & 63.4 & 5.3 & 154 & 21 & 47 & 0.63 & P. expansum \\
\hline 7 & ATPase & KGO37099.1 & 47.1 & 5.2 & 135 & 19 & 53 & 0.25 & P. expansum \\
\hline 8 & Hexokinase & KGO52770.1 & 54.4 & 5.2 & 107 & 20 & 46 & 0.19 & P. expansum \\
\hline 11 & Phosphoglycerate kinase & KGO47626.1 & 43.7 & 5.6 & 90 & 13 & 43 & 0.65 & P. expansum \\
\hline 15 & $\begin{array}{l}\text { Aldose 1-/Glucose-6-phosphate } \\
\text { 1-epimerase }\end{array}$ & KGO37445.1 & 34.9 & 4.9 & 83 & 7 & 46 & 0.52 & P. expansum \\
\hline 16 & $\begin{array}{l}\text { Aldose 1-/Glucose-6-phosphate } \\
\text { 1-epimerase }\end{array}$ & KXG45800.1 & 32.8 & 5.1 & 93 & 7 & 40 & 0.42 & P. expansum \\
\hline 18 & $\begin{array}{l}\text { NAD binding NADP } \\
\text { oxidoreductase coenzyme }\end{array}$ & ATY61637.1 & 32.3 & 6.4 & 86 & 7 & 49 & 0.53 & $\begin{array}{l}\text { Cordyceps } \\
\text { militaris }\end{array}$ \\
\hline 19 & $\begin{array}{l}\text { Glyceraldehyde/Erythrose } \\
\text { phosphate dehydrogenase }\end{array}$ & KGO37673.1 & 31.4 & 4.7 & 88 & 7 & 38 & 0.38 & P. expansum \\
\hline 20 & $\begin{array}{l}\text { Short-chain dehydrogenase/ } \\
\text { reductase SDR }\end{array}$ & XP_003835031.1 & 30.5 & 5.4 & 83 & 6 & 56 & 0.57 & $\begin{array}{l}\text { Leptosphaeria } \\
\text { maculans }\end{array}$ \\
\hline \multicolumn{10}{|c|}{ Antibiotic resistance and defense response } \\
\hline 13 & $\begin{array}{l}\text { Aminoglycoside } \\
\text { phosphotransferase }\end{array}$ & XP_016598064.1 & 41.4 & 5.6 & 89 & 8 & 42 & 1.59 & P. expansum \\
\hline 22 & Peroxiredoxin, AhpC-type & XP_016601946.1 & 24.7 & 5.2 & 83 & 7 & 51 & 1.62 & P. expansum \\
\hline 25 & ABC multidrug transporter & OQE72650.1 & 18.2 & 5.1 & 74 & 5 & 43 & 1.94 & P. nalgiovense \\
\hline \multicolumn{10}{|c|}{ Protein Transport } \\
\hline 14 & $\begin{array}{l}\text { Vacuolar protein sorting-associated } \\
\text { protein } 26\end{array}$ & KGO49711.1 & 40.8 & 7.0 & 75 & 6 & 19 & 2.70 & P. expansum \\
\hline \multicolumn{10}{|c|}{ Secondary metabolism } \\
\hline 23 & $\begin{array}{l}\text { S-adenosylmethionine dependent } \\
\text { methyltransferase }\end{array}$ & XP_016598675.1 & 24.6 & 5.0 & 84 & 8 & 49 & 1.91 & P. expansum \\
\hline \multicolumn{10}{|c|}{ Unknown protein } \\
\hline 8 & hypothetical protein & OQD64464.1 & 45.1 & 6.7 & 64 & 6 & 24 & 0.60 & P. expansum \\
\hline 9 & hypothetical protein & OQD64464.1 & 45.1 & 6.8 & 84 & 8 & 33 & 0.55 & P. polonicum \\
\hline 21 & hypothetical protein & EPS25373.1 & 27.0 & 4.8 & 79 & 4 & 31 & 0.42 & P. oxalicum \\
\hline 26 & hypothetical protein & XP_016595490.1 & 18.1 & 5.6 & 118 & 9 & 60 & 2.41 & P. expansum \\
\hline
\end{tabular}



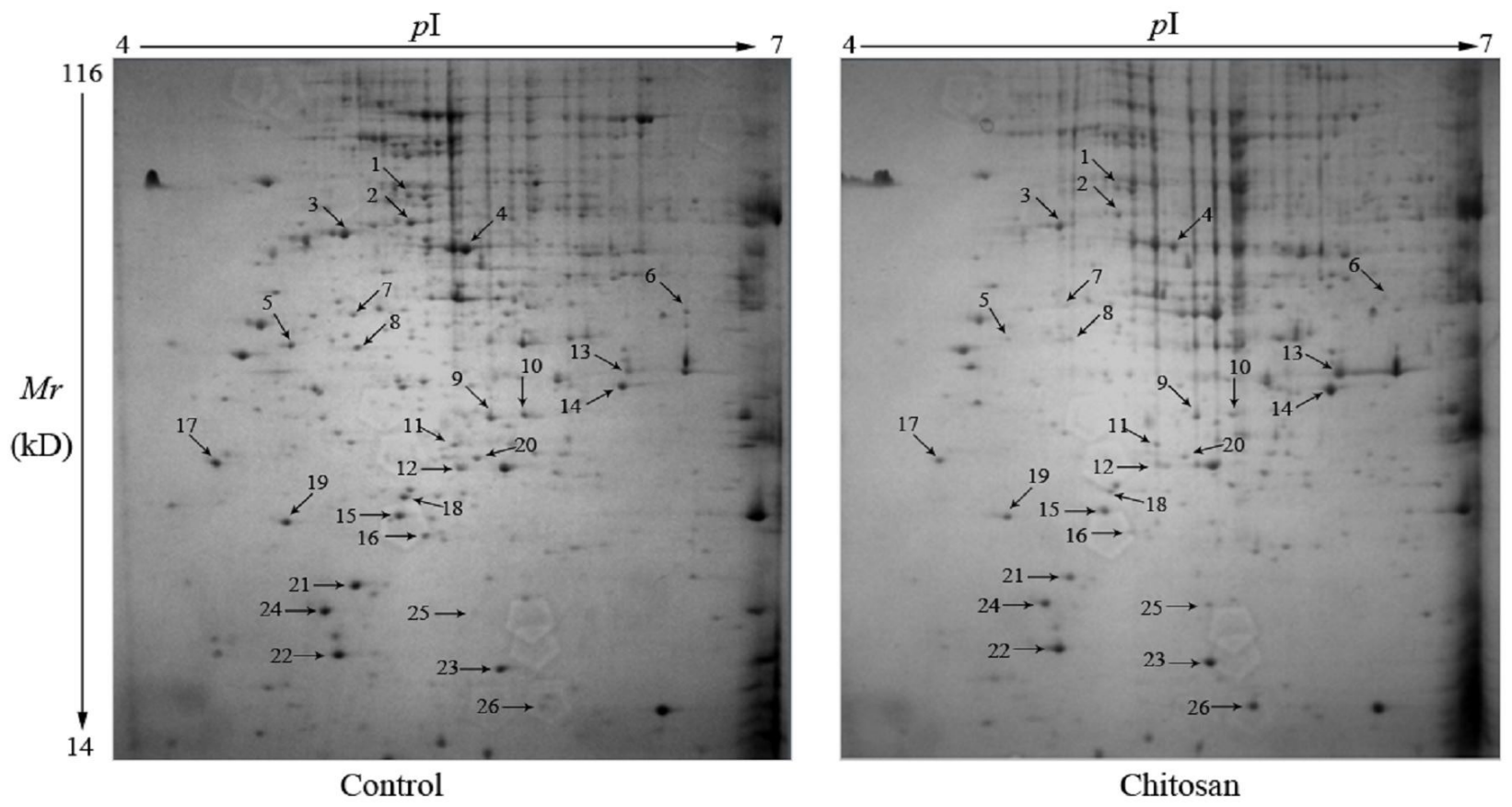

Figure 4. Two-dimensional electrophoresis of P. expansum with or without $0.05 \%$ chitosan treatment.

(spot 6) and translational elongation factor (spot 5 and 24). This finding is in accordance with the work of Márquez et al. (2013), in which gene deletion array was employed to screen and identify chitosan-regulated cellular pathway in Saccharomyces cerevisiae and the results clearly indicated that chitosan can directly interfere with fungi protein synthesis and cell membranes. It has been reported that electrostatic interactions is potentially occurred between positively charged $-\mathrm{NH}_{2}$ groups on polysaccharide chain of chitosan and negatively charged phosphate groups on nucleic acid chain, or - $\mathrm{COOH}$ groups on protein (Boeris et al., 2011; Moussa et al., 2013). These interactions between chitosan and biomacromolecules in microbial cell could partially explain the inhibitory effect of chitosan on spore germination and mycelium growth and could also help to explain our proteomic findings that proteins involved in DNA or protein biosynthesis decreased in relative protein abundance after exposure to chitosan.

A number of proteins related to carbohydrate metabolism and energy production, including thiamine pyrophosphate enzyme (spot 3), ATPase (spot 7), hexokinase (spot 8), phosphoglycerate kinase (spot 11), aldose1-/glucose-6-phosphate 1-epimerase (spot 15 and 16), NAD binding NADP oxidoreductase coenzyme (spot 18) were found to be reduced by chitosan treatment. These enzymes are mainly involved in glycolytic pathway and Kreb's cycle, generating NADH and ATP. Spot 20 was identified as short-chain dehydrogenase/ reductase which plays a important role in lipid, carbohydrate, amino acid, cofactor and xenobiotic metabolism (Kavanagh et al., 2008), and was identified to be reduced by chitosan treatment in Neurospora crassa (Lopez-Moya et al., 2016). Consistent with our results, previous transcriptomic studies revealed that chitosan treatment could disrupt the cellular energy production and reduces the expression of genes associated with lipid, carbohydrate and coenzyme metabolism in Staphylococcus aureus (Raafat et al., 2008) and S. cerevisiae (Jaime et al., 2012).

Proteins related to antibiotics resistance and antioxidant defense response, including aminoglycoside phosphotransferase (spot 13), peroxiredoxin (spot 22) and ABC multidrug transporter (spot 25), increased in relative abundances after chitosan treatment. This finding is not unprecedented; for example, the expression levels of peroxiredoxin and a number of other proteins related to reactive oxygen species homeostasis in $N$. crassa were induced by chitosan treatment (Lopez-Moya et al., 2016). Oxidative stress was also observed in chitosan treated $U$. maydis (Olicón-Hernández et al., 2017); therefore, increased expression of these proteins may be associated with an imbalance of the intracellular redox state. Moreover, spot 25 was identified as an $\mathrm{ABC}$ multidrug transporter, which is known to be involved in extrusion of antifungal drugs (Cavalheiro et al., 2018). It has been assumed that chitosan could enter into fungi cell thereby causing physiological disturbance (Palma-Guerrero et al., 2009). Therefore, activation of this efflux system might contribute to protection of fungi cells from hostile environment (Sanglard et al., 2009).

S-adenosylmethionine dependent methyltransferase (spot 23), which plays a key role in the transfer of methyl groups to various biomolecules, increased in relative protein abundance after chitosan treatment. Increased expression of S-adenosylmethionine dependent methyltransferase at transcriptional level has been reported in chitosan-treated S. cerevisiae, which appears to be a possible stratagem employed by fungi cells for chitosan tolerance (Zakrzewska et al., 2005). Spot 14 was identified as vacuolar protein sorting-associated protein and known to be participated in the sorting and delivery of soluble vacuolar proteins to vacuole (Bonangelino et al., 2002). The vacuolar protein sorting-associated protein deletion strain of yeast $S$. cerevisiae exhibited more 
sensitive than the wild type to chitosan, suggesting that induced expression of this protein might provide some protection against chitosan treatment (Jaime et al., 2012).

\section{Conclusion}

In summary, the results described in this paper demonstrate that chitosan strongly inhibits fungal growth and induces remarkable morphological and ultrastructural changes in P. expansum. Differential proteomic analysis reveals that proteins involved in DNA or protein biosynthesis and energy production decreased in relative protein abundance, while proteins associated with antibiotics resistance and defense response increased in relative protein abundance after chitosan treatment, which might explain the antifungal activity of chitosan against $P$. expansum.

\section{Acknowledgements}

This study was financially supported by the National Key Technology Research and Development Program of China (2015BAK45B00) and Practice Innovation Training Program Project of College Students in Jiangsu Province, China granted to C. Chen (201610299011Z).

\section{References}

Al-Hetar, M. Y., Abidin, M. A. Z., Sariah, M., \& Wong, M. Y. (2011). Antifungal activity of chitosan against Fusarium oxysporum f. sp cubense. Journal of Applied Polymer Science, 120(4), 2434-2439. http://dx.doi.org/10.1002/app.33455.

Andersen, B., Smedsgaard, J., \& Frisvad, J. C. (2004). Penicillium expansum: consistent production of patulin, chaetoglob osins, and other secondary metabolites in culture and their natural occurrence in fruit products. Journal of Agricultural and Food Chemistry, 52(8), 2421-2428. http://dx.doi.org/10.1021/jf035406k.

Boeris, V., Micheletto, Y., Lionzo, M., Silveira, N. P., \& Picó, G. (2011). Interaction behavior between chitosan and pepsin. Carbohydrate Polymers, 84(1), 459-464. http://dx.doi.org/10.1016/j.carbpol.2010.12.008.

Bonangelino, C. J., Chavez, E. M., \& Bonifacino, J. S. (2002). Genomic screen for vacuolar protein sorting genes in Saccharomyces cerevisiae. Molecular Biology of The Cell, 13(7), 2486-2501. http://dx.doi. org/10.1091/mbc.02-01-0005.

Cai, H., Yuan, X., Pan, J., Li, H., Wu, Z., \& Wang, Y. (2014). Biochemical and proteomic analysis of grape berries (Vitis labruscana) during cold storage upon postharvest salicylic acid treatment. Journal of Agricultural and Food Chemistry, 62(41), 10118-10125. http://dx.doi. org/10.1021/jf503495z.

Cavalheiro, M., Pais, P., Galocha, M., \& Teixeira, M. C. (2018). HostPathogen interactions mediated by MDR transporters in fungi: as pleiotropic as it gets. Genes, 9(7), 1-29. http://dx.doi.org/10.3390/ genes9070332. PMid:30004464.

Cota-Arriola, O., Cortez-Rocha, M. O., Rosas-Burgos, E. C., BurgosHernández, A., López-Franco, Y. L., \& Plascencia-Jatomea, M. (2011). Antifungal effect of chitosan on the growth of Aspergillus parasiticus and production of aflatoxin B1. Polymer International, 60(6), 937-944. http://dx.doi.org/10.1002/pi.3054.

Dias, A. M., Cabrera, M. P. D., Lima, A. M. F., Taboga, S. R., Vilamaior, P. S. L., Tiera, M. J., \& Tiera, V. A. D. (2018). Insights on the antifungal activity of amphiphilic derivatives of diethylaminoethyl chitosan against Aspergillus flavus. Carbohydrate Polymers, 196, 433-444. http://10.1016/j.carbpol.2018.05.032.

El Hassni, M., El Hadrami, A., Daayf, F., Ait Barka, E., \& El Hadrami, I. (2004). Chitosan, antifungal product against Fusarium oxysporum f. sp. albedinis and elicitor of defence reactions in date palm roots. Phytopathologia Mediterranea, 43, 195-204.

Garcia-Rincon, J., Vega-Perez, J., Guerra-Sanchez, M. G., HernandezLauzardo, A. N., Pena-Diaz, A., \& Velazquez-Del Valle, M. G. (2010). Effect of chitosan on growth and plasma membrane properties of Rhizopus stolonifer (Ehrenb.:Fr.) Vuill. Pesticide Biochemistry and Physiology, 97(3), 275-278. http://dx.doi.org/10.1016/j. pestbp.2010.03.008.

Hadwiger, L. A. (2013). Multiple effects of chitosan on plant systems: solid science or hype. Plant Science, 208, 42-49. http://dx.doi. org/10.1016/j.plantsci.2013.03.007.

Jaime, M. D., Lopez-Llorca, L. V., Conesa, A., Lee, A. Y., Proctor, M., Heisler, L. E., Gebbia, M., Giaever, G., Westwood, J. T., \& Nislow, C. (2012). Identification of yeast genes that confer resistance to chitosan oligosaccharide (COS) using chemogenomics. BMC Genomics, 13, 267-267. http://dx.doi.org/10.1186/1471-2164-13-267.

Kavanagh, K. L., Jörnvall, H., Persson, B., \& Oppermann, U. (2008). Medium-and short-chain dehydrogenase/reductase gene and protein families. Cellular and Molecular Life Sciences, 65(24), 3895-3906. http://dx.doi.org/10.1007/s00018-008-8591-3.

Li, H., Wang, Y., Liu, F., Yang, Y., Wu, Z., Cai, H., Zhang, Q., Wang, Y., \& Li, P. (2015). Effects of chitosan on control of postharvest blue mold decay of apple fruit and the possible mechanisms involved. Scientia Horticulturae, 186, 77-83. http://dx.doi.org/10.1016/j. scienta.2015.02.014.

Liu, J., Sui, Y., Wisniewski, M., Droby, S., \& Liu, Y. S. (2013). Review: utilization of antagonistic yeasts to manage postharvest fungal diseases of fruit. International Journal of Food Microbiology, 167(2), 153-160. http://dx.doi.org/10.1016/j.ijfoodmicro.2013.09.004.

Lopes, U. P., Zambolim, L., Costa, H., Pereira, O. L., \& Finger, F. L. (2014). Potassium silicate and chitosan application for gray mold management in strawberry during storage. Crop Protection, 63, 103-106. http://dx.doi.org/10.1016/j.cropro.2014.05.013.

Lopez-Moya, F., Kowbel, D., Nueda, M. J., Palma-Guerrero, J., Glass, N. L., \& Lopez-Llorca, L. V. (2016). Neurospora crassa transcriptomics reveals oxidative stress and plasma membrane homeostasis biology genes as key targets in response to chitosan. Molecular Biosystems, 12(2), 391-403. http://dx.doi.org/10.1039/c5mb00649j.

Márquez, I. G., Akuaku, J., Cruz, I., Cheetham, J., Golshani, A., \& Smith, M. L. (2013). Disruption of protein synthesis as antifungal mode of action by chitosan. International Journal of Food Microbiology, 164(1), 108-112. http://dx.doi.org/10.1016/j.ijfoodmicro.2013.03.025.

Moussa, S. H., Tayel, A. A., \& Al-Turki, A. I. (2013). Evaluation of fungal chitosan as a biocontrol and antibacterial agent using fluorescencelabeling. International Journal of Biological Macromolecules, 54, 204-208. http://dx.doi.org/10.1016/j.ijbiomac.2012.12.029.

Munhuweyi, K., Lennox, C. L., Meitz-Hopkins, J. C., Caleb, O. J., Sigge, G. O., \& Opara, U. L. (2017). Investigating the effects of crab shell chitosan on fungal mycelial growth and postharvest quality attributes of pomegranate whole fruit and arils. Scientia Horticulturae, 220, 78-89. http://dx.doi.org/10.1016/j.scienta.2017.03.038.

Olicón-Hernández, D. R., Hernández-Lauzardo, A. N., Pardo, J. P., Peña, A., Velázquez-del Valle, M. G., \& Guerra-Sánchez, G. (2015). Influence of chitosan and its derivatives on cell development and physiology of Ustilago maydis. International Journal of Biological Macromolecules, 79, 654-660. http://dx.doi.org/10.1016/j.ijbiomac.2015.05.057. 
Olicón-Hernández, D. R., Uribe-Alvarez, C., Uribe-Carvajal, S., Pardo, J. P., \& Guerra-Sánchez, G. (2017). Response of Ustilago maydis against the stress caused by three polycationic chitin derivatives. Molecules, 22(12), 1-11. http://dx.doi.org/doi:10.3390/molecules22121745.

Palma-Guerrero, J., Huang, I. C., Jansson, H. B., Salinas, J., LopezLlorca, L. V., \& Read, N. D. (2009). Chitosan permeabilizes the plasma membrane and kills cells of Neurospora crassa in an energy dependent manner. Fungal Genetics and Biology, 46(8), 585-594. http://dx.doi.org/10.1016/j.fgb.2009.02.010.

Palma-Guerrero, J., Jansson, H. B., Salinas, J., \& Lopez-Llorca, L. V. (2008). Effect of chitosan on hyphal growth and spore germination of plant pathogenic and biocontrol fungi. Journal of Applied Microbiology, 104(2), 541-553. http://dx.doi.org/10.1111/j.1365-2672.2007.03567.x.

Plascencia-Jatomea, M., Viniegra, G., Olaya, R., Castillo-Ortega, M. M., \& Shirai, K. (2003). Effect of chitosan and temperature on spore germination of Aspergillus niger. Macromolecular Bioscience, 3(10), 582-586. http://dx.doi.org/10.1002/mabi.200350024.

Prapagdee, B., Kotchadat, K., Kumsopa, A., \& Visarathanonth, N. (2007). The role of chitosan in protection of soybean from sudden death syndrome caused by Fusarium solani f. sp. glycines. Bioresource Technology, 98(7), 1353-1358. http://dx.doi.org/10.1016/j. biortech.2006.05.029.

Puel, O., Galtier, P., \& Oswald, I. P. (2010). Biosynthesis and toxicological effects of patulin. Toxins, 2(4), 613-631. http://dx.doi.org/10.3390/ toxins 2040613.

Raafat, D., von Bargen, K., Haas, A., \& Sahl, H. G. (2008). Insights into the mode of action of chitosan as an antibacterial compound. Applied and Environmental Microbiology, 74(12), 3764-3773. http:// dx.doi.org/10.1128/AEM.00453-08.

Rabea, E. I., \& Steurbaut, W. (2010). Chemically modified chitosans as antimicrobial agents against some plant pathogenic bacteria and fungi. Plant Protection Science, 46(4), 149-158. http://dx.doi. org/10.17221/9/2009-PPS.
Sanglard, D., Coste, A., \& Ferrari, S. (2009). Antifungal drug resistance mechanisms in fungal pathogens from the perspective of transcriptional gene regulation. FEMS Yeast Research, 9(7), 1029-1050. http://dx.doi. org/10.1111/j.1567-1364.2009.00578.x.

Wang, L., Wu, H., Qin, G., \& Meng, X. (2014). Chitosan disrupts Penicillium expansum and controls postharvest blue mold of jujube fruit. Food Control, 41, 56-62. http://dx.doi.org/10.1016/j. foodcont.2013.12.028.

Wang, Y., Kroon, J. K. M., Slabas, A. R., \& Chivasa, S. (2013). Proteomics reveals new insights into the role of light in cadmium response in Arabidopsis cell suspension cultures. Proteomics, 13(7), 1145-1158. http://dx.doi.org/10.1002/pmic.201200321.

Xing, K., Xing, Y., Liu, Y., Zhang, Y., Shen, X., Li, X., Miao, X., Feng, Z., Peng, X., \& Qin, S. (2018). Fungicidal effect of chitosan via inducing membrane disturbance against Ceratocystis fimbriata. Carbohydrate Polymers, 192, 95-103. http://dx.doi.org/10.1016/j. carbpol.2018.03.053.

Xing, K., Zhu, X., Peng, X., \& Qin, S. (2015). Chitosan antimicrobial and eliciting properties for pest control in agriculture: a review. Agronomy for Sustainable Development, 35(2), 569-588. http:// dx.doi.org/10.1007/s13593-014-0252-3.

Yuan, X., Wu, Z., Li, H., Wang, Y., Liu, F., Cai, H., Newlove, A. A., \& Wang, Y. (2014). Biochemical and proteomic analysis of 'Kyoho' grape (Vitis labruscana) berries during cold storage. Postharvest Biology and Technology, 88, 79-87. http://dx.doi.org/10.1016/j. postharvbio.2013.10.001.

Zakrzewska, A., Boorsma, A., Brul, S., Hellingwerf, K. J., \& Klis, F. M. (2005). Transcriptional response of Saccharomyces cerevisiae to the plasma membrane-perturbing compound chitosan. Eukaryotic Cell, 4(4), 703-715. http://dx.doi.org/10.1128/EC.4.4.703-715.2005.

Zhang, H., Li, R., \& Liu, W. (2011). Effects of chitin and its derivative chitosan on postharvest decay of fruits: a review. International of Journal of Molecular Science, 12(2), 917-934. http://dx.doi.org/10.3390/ ijms12020917. 